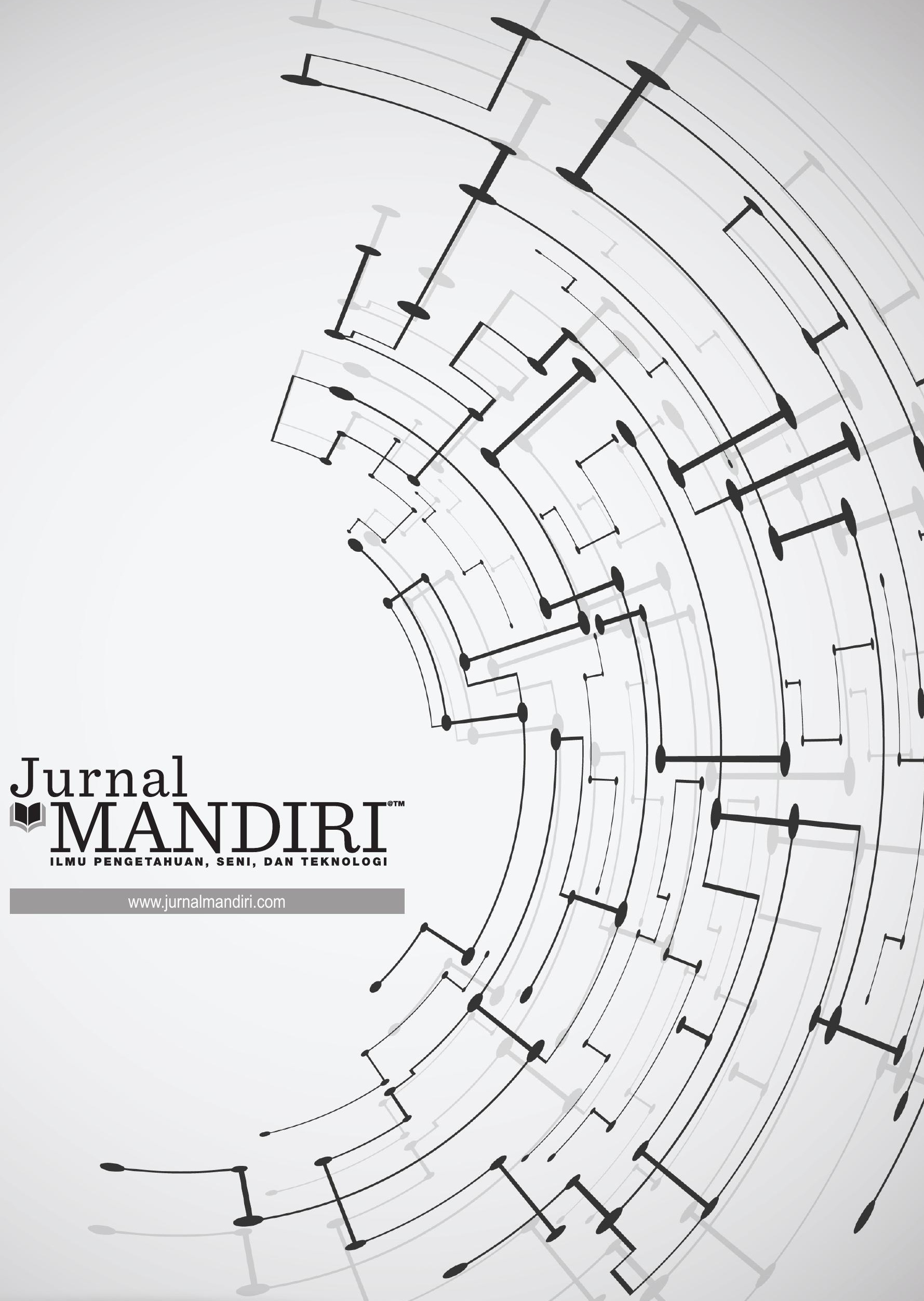


ISSN : 2580-3220, E-ISSN : 2580-4588

J. Mandiri., Vol. 3, No. 1, Juni 2019 (99 - 115)

(C)2018 Lembaga Kajian Demokrasi

dan Pemberdayaan Masyarakat (LKD-PM)

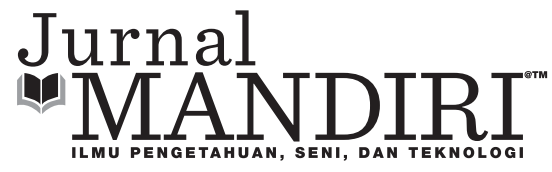

\title{
ANALISIS KONSEP ETIKA BISNIS TRANSAKSI JUAL BELI DI PASAR TRADISIONAL SELASA PANAM KECAMATAN TAMPAN KOTA PEKANBARU PERSPEKTIF EKONOMI ISLAM
}

\author{
Nurhadi \\ Sekolah Tinggi Agama Islam Al-Azhar Pekanbaru \\ alhadijurnal@gmail.com; alhadicentre@yahoo.co.id \\ Soleh Wati \\ Fakultas Syariah dan Hukum, UIN Suska Riau \\ soleh.wati36@gmail.com
}

\begin{abstract}
Abstrak
Penelitian ini merupakan penelitian lapangan (field research) di Jalan HR. Soebrantas Panam, Tuah Karya, Tampan, Kota Pekanbaru. Yang melatar belakanginya adalah bahwa pedagang harus menerapkan etika bisnis dalam transaksi jual beli, namun di pasar tradisional selasa Panam Kecamatan Tampan Kota Pekanbaru masih melakukan penyimpangan diantaranya: pengurangan takaran dari timbangan, menyembunyikan cacat barang, dan juga ada bebera papedagang ketika melayani pembeli tidak bersikap ramah atau murah hati, hal ini dapat dilihat dari raut wajah yang kurang bersahabat. Lalu bagaimana tinjauan Ekomoni Syariah terhadap etika bisnis transaksi jual beli di pasar tersebut?. Subjek penelitian para pedagang, objeknya perilaku bisnis. Teknik pengumpulan data dengan observasi, wawancara dan dokumentasi. Analisis datanya bersifat deskriptif Analisis dimana data yang diperoleh dianalisis dan disajikan dalam bentuk tabel analisis. Berdasarkan hasil observasi dan kuesioner yang diperoleh dari para pedagang maka ada beberapa poin etika bisnis yang diterapkan, yaitu halal, amanah, keadilan, tidak memaksa dan ikhtikar, maka hal ini sudah sesuai dengan etika bisnis dalam transaksi jual beli menurut Ekonomi Syariah. Namun pada poin jujur dan riba masih terdapat tindakan kecurangan yang tidak sesuai. Maka dapat disimpulkan bahwa etika bisnis dalam transaksi jual beli di pasar tradisional Selasa Panam Tampan Pekanbaru yang ditinjau menurut Ekonomi Syariah secara umum belum diterapkan dengan baik oleh para pedagang. Pedagang masih melakukan penipuan (mengurangi takaran, menyembunyikan cacat barang, dan lainnya), hal ini bertentangan dengan syariat Islam.
\end{abstract}

Kata Kunci : Analisis, Konsep, Etika Bisnis, Transaksi, Jual Beli

\begin{abstract}
This research is a field research in Jalan HR. Soebrantas Panam, Tuah Karya, Tampan, Pekanbaru City. The background is that traders must apply business ethics in buying and selling transactions, but in the traditional market of Selasa Panam Subdistrict Tampan Pekanbaru City still do irregularities including: reducing the dose of the scales, hiding defects in goods, and also there are some traders when serving buyers not being friendly or generous, this can be seen from a less friendly face. Then what about the Sharia Ecomony review of the business
\end{abstract}


ethics of buying and selling transactions in the market? The subject of research for traders, the object of business behavior. Data collection techniques with observation, interviews and documentation. Analysis of the data is descriptive analysis where the data obtained is analyzed and presented in the form of an analysis table. Based on the results of observations and questionnaires obtained from traders, there are several points of business ethics that are applied, namely halal, trustworthiness, justice, non-coercion and endorsement, so this is in line with business ethics in buying and selling transactions according to the Sharia Economy. However, at honest and usury points there are still fraudulent actions that are not appropriate. So it can be concluded that business ethics in buying and selling transactions in the traditional markets Tuesday Panam Tampan Pekanbaru which are reviewed according to the Sharia Economy in general have not been well implemented by traders. Traders still commit fraud (reducing doses, hiding defects of goods, and others), this is contrary to Islamic law.

Keywords : Analysis, Concepts, Business Ethics, Transactions, Buying and Selling.

\section{PENDAHULUAN}

\section{Latar Belakang}

Ekonomi merupakan satu kesatuan yang tidak dapat dipisahkan dari nilai-nilai yang melingkupinya. Ekonomi memiliki koneksi dan berdialektika dengan nilai sosial dan budaya masyarakat, bahkan ekonomi mentransmisikan kekuatan potensialnya, mempengaruhi serta membentuk realitas atau lingkungan tempat dimana ekonomi dipraktikkan (Muhammad, 2014: 2). Sedangkan pasar secara sederhana bisa diartikan sebagai tempat bertemunya para penjual dan pembeli untuk melakukan transaksi (Kasmir, el, 2010: 43).

Ekonomi pasar merupakan suatu sistem ekonomi yang dikontrol, diatur, dan diarahkan oleh pasar itu sendiri. Peraturan dalam produksi dan distribusi barang dipercayakan kepada mekanisme itu sendiri. Ekonomi jenis ini berasal dari suatu harapan bahwa umat manusia akan mengambil sikap sedemikian rupa untuk mendapat untung sebanyak-banyaknya. Sistem ekonomi ini menganggap pasar sebagai tempat penyediaan barang, termasuk jasa, dengan harga tertentu yang berdasarkan harga tadi akan memenuhi permintaan (Damsar, 2012: 84).

Dalam sistem pasar yang demikian, konsumen merupakan faktor yang penting dan menentukan kedudukan pasar tersebut. Konsumen akanmenentukan barang dan jasa yang mereka kehendaki, dengan kata lain, terjadi saling ketergantungan antara pedagang dan pembeli (Nejatullah, 2016: 81).
Etika adalah disiplin ilmu yang memberikan pengetahuan tentang apa yang benar dan apa yang salah. Etika sebagai ilmu yang dapat diartikan sabagai nilai-nilai dan norma moral dalam suatu masyarakat (Harahap, 2011: 69).

Etika mempunyai kedudukan yang sangat penting dalam kehidupan manusia, baik sebagai individu, anggota masyarakat maupun anggota suatu bangsa. Etika berasal dari bahasa Latin etos yang berarti 'kebiasaan', sinonimnya adalah moral, juga berasal dari bahasa yang sama 'mores' yang berarti 'kebiasaan'. Sedangkan bahasa Arabnya akhlak bentuk jama' dari mufradatnya khuluq artinya budi pekerti.Keduanya bisa diartikan sebagai kebiasaan atau adat istiadat yang menunjukkan kepada prilaku manusia itu sendiri, tindakan atau sikap yang dianggap benar atau baik (Hasan, 2016: 171-172).

Bisnis adalah pertukaran barang, jasa atau uang yang saling menguntungkan atau memberi manfaat. Secara sederhana bisnis adalah semua kegiatan yang dilakukan oleh seseorang atau lebih yang terorganisasi dalam mencari laba melalui penyediaan produk yang dibutuhkan oleh masyarakat (Tantri, 2015: 4).

Etika Islam yang mewarnai sistem ekonomi Islam bermaksud menjelaskan bahwa Islam sebagai way of life merupakan bentuk ibadah.Sehingga tak seorangpun boleh menganggap bahwa Islam hanya terfokus pada aspek ritualitas keagamaan, tanpa aspek social-economi yang, yang melingkupinya. Ekonomi Islam dengan etikanya bermaksud untuk menggabungkan masalah du- 
nia dan akhirat. (Aziz, 2013: 97).

Dalam ekonomi Islam, bisnis dan etika tidak harus dipandang sebagai dua hal yang bertentangan, sebab bisnis yang merupakan simbol urusan duniawi, juga dianggap sebagai bagian integral dari hal-hal yang bersifat investasi akhirat. Artinya, jika orientasi bisnis dan upaya interval akhirat (diniatkan sebagai ibadah merupakan totalitas kepatuhan kepada tuhan), bisnis dengan sendirinya harus sejalan dengan kaidah-kaidah moral yang berlandaskan keimanan kepada akhirat. Bahkan dalam Islam pengertian bisnis tidak dibatasi urusan dunia, tatapi mencakup pula seluruh kegiatan di dunia yang dibisniskan (diniatkan sebagai ibadah) untuk meraih keuntungan atau pahala akhirat. (Aziz, 2013: 97-98).

Pasar selasa Panam berada di Kelurahan Tuah Karya, merupakan salah satu kelurahan yang berada di Kecamatan Tampan. Pasar yang ramai pada hari selasa ini ramai didatangi para pedagang dalam dan luar daerah seperti pedagang yang berasal dari Kampar. Adapun masyarakat yang berbelanja di pasar tidak hanya dari Kelurahan tuah Karya, melainkan banyak juga yang berasal dari luar kelurahan bahkan luar Kecamatan Tampan.

Secara umum pasar terdiri dari dua jenis, yaitu pasar tradisional dan pasar modern. Maka pasar yang peneliti hendak teliti adalah pasar Selasa Simpang Baru kelurahan Tuah Karya kecamatan Tampan kota Pekanbaru adalah kategori Pasar Tradisional.

Dari pengamatan penulis, masih banyak ditemukan pedagang yang mengabaikan etika dalam menjalankan bisnisnya. Masih banyak pedagang yang melakukan penyimpangan-penyimpangan dalam berdagang. Beberapa penyimpangan yang ditemukan di pasar tradisional tersebut, Misalnya pengurangan timbangan dan takaran, pengoplosan barang yang berkualitas bagus dengan yang buruk, pedagang yang memberikan pelayanan yang kurang baik serta saling menjatuhkan pedagang lain. (Observasi, 2017).

Kenyataan yang telah terjadi di Pasar terhadap etika perdagangan saat ini adalah telah terjadi pergeseran etika dalam dagang atau bis- nis. Selama ini para pedagang memahami bisnis adalah bisnis, yang bertujuan memperoleh keuntungan sebanyak-banyaknya dengan menghalalkan segala cara untuk meraih keuntungan. Para pedagang masih kurang memahami etika yang diterapkan oleh Islam, karena kurang pemahaman, para pedagang tidak menyadari pentingnya berdagang dengan etika yang sesuai dalam Islam. (Putra, 2017).

Sebagian pedagang banyak mengalami kendala saat mengetahui kondisi barangnya mengalami cacat. Pedagang kesulitan dalam hal ini, karena apabila dijelaskan kepada pembeli, maka pedang akan mengalami rugi disebabkan tidak laku. Dan sebagian pembeli kadang tidak menanyakan kondisi barang tersebut. (Putri, 2017).

Hal tersebut diperkuat dengan adanya pernyataan pelanggan pasar tradisional selasa yang pernah mendapatkan kecurangan timbangan dalam berbelanja. Salah satunya pengakuan ibu Tia, bahwa ia membeli buah seberat $1 \mathrm{~kg}$, ketika ia hendak membeli buah berbeda di tempat yang berbeda dengan berat yang sama yakni $1 \mathrm{~kg}$, tampak perbedaan pada kedua buah yang ibu Tia beli, kemudian ia timbang kembali buah pertama tersebut dan ternyata kurang satu ons dari takaran yang sebenarnya. (Fatimah, 2017).

Fenomena ini menggambarkan bahwa beberapa pedagang di pasar tradisional Selasa Panam masih kurang melakukan penerapan etika bisnis Islam. Mereka masih berorientasi pada keuntungan duniawi saja dan meninggalkan etika bisnisnya.

\section{Rumusan Masalah}

Berdasarkan latar belakang masalah diatas, maka peneliti akan membuat rumusan maslah dalam bentuk pertanyaan, yaitu: bagaimana tinjauan Ekomoni Syariah terhadap etika bisnis pedagang pasar selasa simpang baru kelurahan Tuah Karya kecamatan Tampan kota Pekanbaru pada transaksi jual beli?

\section{METODE}

Adapun lokasi penelitian ini adalah pedagang pasar Selasa Simpang Baru kelurahan 
Tuah Karya kecamatan Tampan kota Pekanbaru. Selanjutnya, penelitian ini dilakukan kepada para pedagang yang ada dilokasi tersebut. Lokasi ini dipilih karena penulis ingin meninjau atau ingin mengetahui etika bisnis pedagang dalam transaksi jual beli yang dilakukan di pasar tersebut, menurut kaca mata etika bisnis Islam. Subyek dalam penelitian ini adalah para pedagang pasar Selasa Simpang Baru kelurahan Tuah Karya kecamatan Tampan kota Pekanbaru. Sedangkan Obyek pada penelitian ini adalah etika bisnis menurut ekonomi Islam. Populasi merupakan jumlah keseluruhan unit analisis, yaitu objek yang akan diteliti. Sedangkan Sampel adalah suatu bagian dari populasi yang akan diteliti dan yang akan dianggap dapat menggambarkan populasinya (Soehartono, 2014: 57).

Penelitian ini menngunakan dua data, yaitu data primer merupakan data yang diperoleh langsung dari para pasar Selasa Simpang Baru kelurahan Tuah Karya kecamatan Tampan kota Pekanbaru dan juga merupakan data yang belum tersedia dan untuk memperoleh data tersebut peneliti harus menggunakan beberapa instrumen penelitian seperti kuesioner, wawancara, observasi dan sebagainya (Tanjung, el, 2013: 76). Dan data sekunder yaitu data yang diperoleh dari sumber kedua atau sumber sekunder dari data yang kita butuhkan (Burhan, 2015: 132). Adapun data tersebut berupa buku, majalah, internet yang berkaitan dengan pemasaran.

Metode pengumpulan data dengan cara observasi dan wawancara. Observasi merupakan metode pengumpulan data dengan cara pengamatan langsung di lapangan untuk mendapatkan gambaran secara nyata tentang kegiatan yang akan diteliti. Wawancara merupakan interaksi dan komunikasi secara langsung, tujuannya untuk memperoleh data yang valid dan akurat. Analisa yang digunakan dalam penelitian ini adalah analisa Deskriptif Kualitatif, data kualitatif berasal dari observasi, wawancara dan angket yang dijelaskan dengan cara menghubungkan antara satu fakta dengan fakta yang lainnya kemudian data itu dianalisa untuk diambil kesimpulan.

\section{HASIL dan PEMBAHASAN}

\section{Historis Pasar Tradisional Selasa Panam}

Pasar tradisional selasa panam awalnya dikenal dengan nama pasar Simpang Baru karena terletak di kelurahan Simpang Baru, namun seiring waktu berjalan pasar ini ramai di kunjungi masyarakat, akan tetapi pasar ini lebih ramai dikunjungi pada hari Selasa dari pada hari-hari biasa lainnya sehingga masyarakat menyebutnya atau lebih dikenal dengan Pasar Selasa Panam. Pada tahun 2000 terjadi pemekaran kelurahan jadi Pasar Selasa Panam Pekanbaru di ambil alih oleh kelurahan Tuah Karya karena Pasar Selasa Panam tersebut terletak di kelurahan Tuah Karya hingga saat ini.

Berdasarkan kepala UPTD Pekanbaru, Bahwasanya masyarakat pedagang Pasar Selasa Panam Pekanbaru menurut tempat berjualannya dapat dilihat pada tabel dibawah ini.

\begin{tabular}{|c|c|c|}
\hline \multicolumn{3}{|c|}{ Tabel I. Jumlah Pedagang Menurut Tempat Usaha Tahun 2017} \\
\hline NO & TEMPAT USAHA & JUMLAH (UNIT) \\
\hline 1 & Kios & 258 \\
\hline 2 & Los & 91 \\
\hline 3 & Payung/ Kaki Lima & 101 \\
\hline & Jumlah & 450 \\
\hline \multicolumn{3}{|c|}{ Sumber: Ka. UPTD Pasar Selasa Panam Pekanbaru, Tahun 201 } \\
\hline
\end{tabular}

Dari data diatas, dapat dilihat bahwa pedagang yang paling banyak berjualan di pasar tradisional selasa Panam menggunakan Kios berjumlah 258 pedagang dengan berbagai macam jenis dagangan.

Berdasarkan jenis barang yang dijual oleh pedagang di pasar tradisional selasa Panam serta jumlah pedagangnya dapat dilihat pada tabel.

\begin{tabular}{|c|c|c|}
\hline \multicolumn{3}{|c|}{$\begin{array}{l}\text { Tabel II. Jumlah Pedagang Menurut Jenis Barang Dagang } \\
\text { Tahun } 2017\end{array}$} \\
\hline NO & JENIS BARANG DAGANGAN & JUMLAH \\
\hline 1 & Barang Harian & 30 \\
\hline 2 & Buah-Buahan & 20 \\
\hline 3 & Lauk Pauk dan Sayuran & 175 \\
\hline 4 & Mainan anak-anak & 7 \\
\hline 5 & Makanan dan Minuman & 50 \\
\hline 6 & Obat-obatan & 10 \\
\hline 7 & Konveksi & 95 \\
\hline 8 & Perabotan Rumah Tangga dan Produksi & 30 \\
\hline 9 & Perhiasan dan aksesoris & 20 \\
\hline 10 & Elektronik & 10 \\
\hline
\end{tabular}




\begin{tabular}{|c|c|c|}
\hline 11 & Alat bangunan & 3 \\
\hline \multicolumn{2}{|c|}{ Jumlah } & 450 \\
\hline \multicolumn{2}{|c|}{ Data: Sumber hasil inventarisasi penulis } \\
\hline
\end{tabular}

Pasar adalah salah satu tempat bertemunya pedagang dan pembeli, sebagai tempat yang mempertemukan antara pedagang dan pembeli, maka pasar menjadi tempat bertemunya atau berkumpulnya sekelompok orang yang terdiri dari berbagai macam suku bangsa diantaranya yaitu suku Melayu, Jawa, Minang, dan Batak. Akan tetapi bahasa sehari-hari yang mereka gunakan adalah bahasa Minang, ini dikarenakan mayoritas pedagang dan pembeli di Pasar Selasa Panam Pekanbaru bersuku Minang, walau sebenarnya disana terdapat suku bangsa lain namun jumlahnya lebih sedikit bila dibandingkan dengan suku Minang.

Pendidikan yang pernah diikuti oleh seseorang sangat berpengaruh terhadap penentuan kualitas sumber daya manusia, semakin tinggi pendidikan yang pernah diikuti oleh seseorang maka semakin bagus pula kualitas sumber daya seseorang tersebut. Pendidikan formal maupun non formal akan menjadi dasar bagi usaha yang dilakukan seseorang. Berdasarkan kepala UPTD Pekanbaru, Bahwasanya masyarakat pedagang Pasar Selasa Panam Pekanbaru pada umumnya mempunyai pendidikan SMA/sederajat.Hal ini dapat dlihat ada tabel di bawah ini.

\begin{tabular}{|c|c|c|}
\hline \multicolumn{3}{|c|}{$\begin{array}{l}\text { Tabel III. Klasifikasi Pendidikan Pedagang } \\
\text { Pasar Selasa Panam Pekanbaru }\end{array}$} \\
\hline NO & ALTERNATIF JAWABAN & FREKUENSI \\
\hline 1 & Akademi / Perguruan Tinggi & 25 \\
\hline 2 & SLTA / Sederajat & 250 \\
\hline 3 & SLTP / Sederajat & 140 \\
\hline 4 & SD / Sederajat & 45 \\
\hline 5 & Tidak Berpendidikan & 0 \\
\hline 6 & Jumlah & 10 \\
\hline & Jumlah & 450 \\
\hline \multicolumn{3}{|c|}{ Sumber: Ka. UPTD Pasar Selasa Panam Pekanbaru. Tahun 201} \\
\hline
\end{tabular}

Dari tabel diatas dapat kita ketahui bahwa seluruh pedagang yang ada di pasar Selasa Panam Pekanbaru berpendidikan, sebagian besar diantara mereka berpendidikan tingkat atas. Hal ini terbukti dengan 25 pedagang yang telah mengikuti perkuliahan, sebanyak 250 pedagang yang berpendidikan SLTA/Sederajat, dan 140 pedagang yang berpendidikan SLTP/Sederajat dan yang berpendidikan SD/Sederajat terdapat 45 pedagang sedangkan yang tidak berpendidikan 0 .

Masyarakat Indonesia adalah masyarakat yang memiliki beraneka ragam suku bangsa dan agama. Begitu juga yang ada di kota Pekanbaru terdiri dari berbagai macam suku bangsa dan agama. Islam tidak melarang umatnya untuk melakukan perdagangan atau jual beli selagi tidak bertentangan dengan aturan agam Islam.

Pedagang Pasar Selasa Panam Pekanbaru adalah pedagang yang mayoritasnya muslim, ada juga yang pedagang non muslim namun jumlahnya sangat sedikit dibandingkan dengan yang muslim baik dari kalangan pedagang maupun pembeli.

\section{Pengertian Etika Bisnis}

Jika ditelusuri secara historis, etika adalah cabang filsafah yang mencari hakikat nilai-nilai baik dan buruk yang berkaitan dengan perbuatan dan tindakan seseorang, yang dilakukan dengan penuh kesadaran berdasarkan pertimbangan pemikirannya. Persoalan etika adalah persoalan yang berhubungan dengan eksistensi manusia, dalam segala aspeknya, baik individu maupun masyarakat, baik yang berhubungan dengan Tuhan, dengan sesama manusia dan dirinya, maupun dengan alam disekitarnya, baik dalam kaitannya dengan eksistensi manusia dibidang social, ekonomi, polotik, budaya maupun agama. (Asy’ari, 2011: 92).

Sementara itu bisnis menurut kamus beras bahasa Indonesia, adalah: a). Usaha dagang, mencari uang dengan cara dagang; b). Usaha komersial didunia perdagangan. Sedangkan Encyclopedia Internasional menyebutkan bahwa bisnis adalah kegiatan manusia yang terlibat di dalam pembelian dan penjualan barang dan jasa dengan tujuan memperoleh keuntungan. (Asy’ari, 2011: 36).

Adapun Etika Bisnis menurut Muslich adalah aplikasi etika umum yang mengatur perilaku bisnis, norma moralitas yang menjadi acuan bisnis dalam prilakunya. Penilaian keberhasilan bisnis tidak saja ditentukan oleh keberhasilan prestasi 
ekonomi dan finansial saja. Namun keberhasilan itu diukur dengan tolak ukur paradigm moralitas dan nilai-nilai etika terutama pada moralitas dan etika yang dilandasi oleh nilai-nilai sosial dan agama. Secara konseptual dapat dinyatakan bahwa proses pencapaian tujuan suatu kegiatan bisnis melalui pengelolaan human dan natural resources, diarahkan pada pengelolaan dan alokasi sumber daya secara optimal bagi semua pihak atau stakebolders. (Tantri: 37 ).

\section{Prinsip Etika Bisnis}

Menurut pendapat Micheal josephson (1998) yang dikutip oleh Zimmerer (1996: 27-28), secara universal, ada 10 prinsip etika yang mengarahkan perilaku, yaitu:

a) Kejujuran, yaitu penuh kepercayaan, bersifat jujur, sungguh-sungguh, terus terang, tidak curang, tidak mencuri, tidak menggelapkan, tidak berbohong. (Anoraga, 2011: 133).

b) Integritas, memegang prinsip melakukan kegiatan yang terhormat, tulus hati, berani dan penuh pendirian/keyakinan, tidak bermuka dua, tidak berbuat jahat dan dapat di percaya. (Anwar, 2014: 97).

c) Memelihara janji, yaitu selalu menaati janji, patut dipercaya, penuh komitmen, patuh tidak mengintepretasikan persetujuan dalam bentuk teknikal atau legalistic dengan dalih ketidakrelaan. (Anwar, 2014: 97).

d) Kesetiaan, yaitu hormat dan loyal kepada keluarga, teman, karyawan, dan negara, tidak menggunakan atau memperlihatkan informasi rahasia, begitu juga dalam suatu konteks profesional, menjaga/ melindungi kemampuan untuk membuat membuat keputusan profesional yang bebas dan teliti, dan menghindari hal yang tidak pantas serta konflik kepentingan. (Anoraga: 133).

e) Kewajaran atau keadilan, yaitu berlaku adil dan berbudi luhur, bersedia mengakui kesalahan, memperlihatkan komitmen keadilan, persamaan perlakuan individual dan toleran terhadap perbedaan, serta tidak bertindak melampaui batas atau mengambil keuntungan profesional yang bebas dan teliti, dan menghindari hal-hal yang tidak pantas serta konflik kepentingan. (Anwar: 97).

f) Suka membantu orang lain, yaitu saling membantu, berbaik hati, belas kasihan, tolong menolong, kebersamaan, dan menghindari segala sesuatu yang membahayakan orang lain. (Anwar: 98).

g) Hormat kepada orang lain, yaitu menghormati martabat orang lain, kebebasan dan hak menentukan nasib sendiri bagi semua orang, bersopan santun, tidak merendahkan dan memperlakukan martabat orang lain. (Anwar: 98-99).

h) Warga Negara yang bertanggung jawab, yaitu selalu menaati hukum dan aturan, penuh kesadaran social, dan menghormati proses demokrasi dalam mengambil keputusan. (Anwar: 99).

i) Mengejar keungulan, yaitu mengejar keunggulan dalam segala hal, baik dalam pertemuan personal ataupun pertanggungjawaban profesional, tekun, dapat dipercaya/diandalkan, rajin penuh komitmen, melakukan semua tugas dengan kemampuan terbaik, dan mengembangkan serta mempertahankan tingkat kompetensi yang tinggi. (Anwar: 99).

j) Dapat dipertanggung jawabkan, yaitu memiliki dan menerima tanggung jawab atas keputusan dan konsekuensinya serta selalu memberi contoh. (Anwar: 97-99).

\section{Pengertian Jual Beli dan Ketentuan Lainnya}

Jual beli atau perdagangan dalam istilah fiqh disebut al-bai' yang menurut etimologi berarti menjual atau mengganti (Rahman, dkk. 2010: 67). Yang dimaksud yaitu:

a) Menukar barang dengan barang atau barang dengan uang yang dlakukan dengan jalan melepaskan hak milik dari yang satu kepada yang lain atas dasar saling merelakan.

b) Pemilikan harta benda dengan jalan tukar menukar yang sesuai dengan aturan syara'.

c) Saling tukar harta, saling menerima, dapat dikelola dengan ijab dan Kabul dengan cara yang sesuai dengan syarat.

d) Tukar menukan benda dengan benda lain dengan cara yang khusus (dibolehkan). 
e) Penukaran benda dengan benda lain dengan jalan saling merelakan atau memindahkan hak milik dengan ada penggantinya dengan cara yang dibolehkan.

f) Akad yang tegak atas dasar penukaran harta dengan harta, maka jadilah penukaran hak milik secara tetap.

Jual beli sebagai sarana tolong menolong antara sesama umat manusia mempunyai landasan yang kuat dalam al-Qur'an dan sunnah Rasulullah saw (Rahman, dkk. 2010: 68). Jual beli adalah merupakan suatu akad, dan dipandang sah apabila telah memenuhi rukun dan syarat jual beli. Mengenai rukun dan syarat jual beli, para ulama berbeda pendapat. Indikator tersebut bisa dalam bentuk perkataan (ijab dan kabul) atau dalam bentuk perbuatan, yaitu saling memberi (penyerahan barang, dan penerimaan uang). Dalam fiqih, hal ini terkenal dengan istilah Bai almuathah.

Menurut jumhur ulama, rukun jual beli itu ada empat, yaitu sebagai berikut (Sahrani, el, 2011: 67): 1). Orang yang berakad (penjual dan pembeli); 2). Sighat (Lafaz ijab dan kabul); 3). Ada barang yang dibeli; 4). Ada nilai tukar pengganti barang.

Menurut H.A Syafii Jafri dalam bukunya yang berjudul Fiqih Muamalah, untuk sahnya jual beli yang dilakukan diperlukan beberapa rukun dan syarat yang harus dipenuhi yaitu: 1). Penjual dan Pembeli, yaitu berakal, bagi yang gila, bodoh dan lainnya tidak sah melakukan jual beli. Kehendak sendiri bukan karena dipaksa. Keadaan tidak mubazir (pemborosan), orang pemboros hartanya dibawah wali. 2). Uang dan benda yang diperjual belikan dengan syarat: Suci, najis tidak sah dijadikan uang dan tidak sah dijual. Bermanfaat, tidak boleh menjual benda yang tidak ada manfaatnya. Dapat dikuasai dan dapat diserahkan, tidak menjual burung yang sedang terbang diudara. Benda dan harganya milik penjual dan pembeli atau sebagai wakil. Pembeli dan penjual mengetahui tentang zat, bentuk, kadar (ukuran) dan sifat-sifat benda tersebut. 3). Sighatul akad, yaitu cara bagaimana ijab dan Kabul yang merupakan rukun akad itu dinyatakan. Sighat akad dapat dlakukan dengan cara lisan, tulisan atau isyarat yang dapat memberikan pengertian dengan jelas tentang adanya ijab dan Kabul, disamping itu sighat akad juga dapat berupa perbuatan yang telah menjadi perbuatan kebiasaan dalam ijab Kabul. (Syafii, 2014: 46-47).

\section{Pengertian Pasar dan Seluk Beluknya}

Pasar dapat diartikan sebagai tempat dimana pembeli dan penjual bertemu untuk mempertukarkan barang-barang mereka, misalnya alun-alun desa. Para ahli ekonomi menggunakan istilah pasar untuk menyatakan sekumpulan penbeli dan penjual yang melakukan transaksi atas suatu produk atau kelas produk tertentu, misalnya pasar perumahan, pasar besar dan lain-lain. Sedangkan dalam manajemen pemasaran konsep pasar terdiri atas semua pelanggan potensial yang mempunyai kebutuhan atau keinginan tertentu yang mungkin bersedia dan mampu melibatkan diri dalam suatu pertukaran guna memuaskan kebutuhan atau keinginan tertentu yang mungkin bersedia dan mampu melibatkan diri dalam suatu pertukaran guna memuaskan kebutuhan atau keinginan tersebut. Pada masa lampau, pasar mengacu pada lokasi geografis, tetapi sekarang ini pasar tidak lagi mempunyai batas-batas geografis karena komunikasi modern telah memungkinkan para pembeli dan penjual untuk mengadakan transaksi tanpa harus bertemu satu sama lain. (Mujahidin, 2014: 141).

Pasar memiliki fungsi sebagai penentu nilai suatu barang, penentu jumlah produksi, mendistribusikan produk, melakukan pembatasan harga, dan menyediakan barang dan jasa untuk jangka panjang.

Pasar tradisional adalah tempat yang dibangun dan dikelola oleh Pemerintah, Pemerintah Daerah, Swasta, Badan Usaha Milik Negara, dan Badan Usaha Milik Daerah yang merupakan tempat bertemunya penjual dan pembeli dalam proses transaksi jual beli secara langsung dalam bentuk eceran dengan proses tawar menawar dan bangunannya biasanya terdiri dari kios-kios atau gerai, los, dan dasaran terbuka yang dibuka oleh penjual maupun pengelola pasar. (https://www. 
google.com, 2018).

Kebanyakan menjual kebutuhan seharihari seperti bahan-bahan makanan berupa ikan, buah, sayur-sayuran, telur, daging, kain, pakaian barang elektronik, jasa dan lain-lain. Selain itu, ada pula yang menjual kue-kue dan barangbarang lainnya. Pasar tradisional biasanya ada dalam waktu sementara atau tetap dengan tingkat pelayanan terbatas. Pasar seperti ini umumnya dapat ditemukan dikawasan permukiman agar memudahkan pembeli untuk mencapai pasar.

\section{Analisis Konsep Etika Bisnis Islami di Pasar Selasa Panam Pekanbaru}

Etika bisnis islam merupakan suatu proses dan upaya untuk mengetahui hal-hal yang benar dan yang salah yang selanjutnya tentu melakukan hal yang benar berkenaan dengan produk, pelayanan perusahaan dengan pihak yang berkepentingan dengan ketentuan perusahaan. Dalam membicarakan etika bisnis Islami adalah menyangkut "Business Firm" dan atau "Busness Person", yang mempunyai arti yang bervariasi. Berbisnis berarti suatu usaha yang menguntungkan. Jadi etika bisnis Islami adalah studi tentang seseorang atau organisasi melakukan usaha atau kontak bisnis yang saling menguntungkan sesuai dengan nilai-nilai ajaran Islam. (Aziz: 35).

Islam tidak hanya mengatur hubungan manusia dengan Allah, tetapi juga memberikan semangat kesadaran nilai yang menjiwai seluruh aktivitas muamalah manusia. Bahkan dalam hal menyangkut urusan dunia (ekonomi dan bisnis), manusia diberikan otonomi untuk membuat keputusan yang memihak pada kesejahteraan manusia sebagai khalifah Allah di muka bumi. (Muhammad, 2014: 64).

Terdapat beberapa hal penting terkait dengan dasar etika dalam bisnis syariah, untuk menganalisis apa yang terjadi di Pasar Selasa Panam Pekanbaru yaitu menyangkut:

1) Jujur. Shidiq (jujur) adalah sifat nabi Muhammad SAW yang artinya berat dan jujur. Seorang pedagang wajib berlaku jujur dalam melakukan usaha jual beli, jujur dalam arti luas tidak berbohong, tidak menipu, tidak mengada-ngada, fakta, tidak berkhianat, serta tidak pernah ingkar janji dan lain sebagainya. Jujur secara umum diakui sebagai keutamaan pertama dan paling penting yang harus dimiliki pelaku bisnis. Dalam menentukan pelaksanaan kejujuran etika bisnis dalam transaksi jual beli di pasar tradisional selasa Panam Kecamatan Tampan Kota Pekanbaru, dapat dilihat dari beberapa hal antara lain:

a) Kecacatan Barang. Cacat barang adalah hal yang wajar dijumpai oleh pedagang, biasanya kecacatan barang ini terjadi saat diperjalanan atau karena penyusutan dan membusuk sebahagian. Berdasarkan hasil observasi yang penulis lakukan di pasar Selasa Panam Kecamatan Tampan Kota Pekanbaru bahwasanya pedagang yang membuka lapak atau dasaran terbuka masih terdapat beberapa pedagang yang melakukan transaksi jual beli terhadap barang yang cacat. Seperti pada pedagang sayuran dan buah-buahan yang masih memperdagangkan barang dagangannya yang sudah tidak bagus lagi atau mengalami kecacatan barang. Pedagang ini biasanya mencampur barang dagangan yang kualitas buruk dengan kualitas bagus, seperti cabe yang bagus dicampur dengan cabe yang sudah mengalami pembusukan. Dalam hal buah-buahan, pedagang biasanya menyembunyikan barang yang mengalami cacat seperti busuk atau memar di bawah buah yang kualitasnya bagus sehingga pembeli tidak menyadari adanya kecacatan barang pada buah tersebut. Pendapat ini diperkuat dengan pernyataan pembeli bu Vivi dan bu Jelita pembeli asal Garuda Sakti yang merasa kecewa dan berpikir lagi untuk membeli buah ditempat sembarangan. Bu Jelita menuturkan "saya pernah membeli buah mangga di pasar, si pedagang membukakan buah mangga yang bagus, segar dan tampak manis kepada saya dan menawarkan buah mangga tersebut 
dengan dalih akan menyesal jika saya tidak membeli. Namun saat saya buka buah mangga yang saya beli tersebut berbeda dari contoh yang diberi oleh pedagang, banyak terdapat mangga yang busuk dan rasa yang masam. (Jelita, 2018)." Pedagang dengan lapak kios dengan jenis dagangan konveksi, aksesoris, dan pedagang bahan harian seperti sembako, masih memperjual belikan barang dagangannya dalam kondisi yang tidak utuh seperti mi instan yang sudah hancur dan tepung yang sudah berkutu. Hal tersebut juga terjadi pada pedagang konveksi yakni menjual barang dagangan yang mengalami kecacatan barang seperti hasil jahitan yang tidak sempurna. Hal ini di perkuat dengan hasil wawancara penulis dengan salah seorang pembeli pada pedagang konveksi ibu Fatiah mengatakan pernah kecewa membeli barang di pasar tradisional Selasa Panam Kecamatan Tampan Kota Pekanbaru, ia membeli sebuah baju, kala itu pedagangnya sedang mengadakan diskon dan ibu Fatiah tertarik membeli sebuah baju potongan dengan harga yang murah, pedagang memberikan barang yang baru kepada ibu Fatiah dan langsung dibungkus oleh pedagang. Ternyata sesampai dirumah bagian ketiak baju jahitannya rusak lumayan besar. Ucap ibu Fatiah. (Fatiah Putri, 2018). Namun pada jenis dagangan aksesoris, pedagang jenis dagangan aksesoris tidak melakukan kecurangan seperti menyembunyikan kecacatan barang. Karena pedagang emas (aksesoris) melakukan penjualan dengan sistem terbuka yakni memperlihatkan secara langsung proses menimbang beserta ukurannya tanpa ada yang disembunyikan. Pedagang lapak los seperti pedagang yang menjual santan, ikan, ayam, daging dan sejenisnya.Menurut pengamatan penulis pedagang jenis dagangan ini tidak menyembunyikan kecacatan barang. Pedagang santan menjual santan kelapa kepada pembeli dengan jujur dan tidak menyembunyikan kecacatan barang.Pedagang ikan dan jenis siput telah menjual barang dagangan dengan tidak menyembunyikan barang dagangannya, yakni pedagang berlaku jujur ketika ada pembeli yang bertanya. Adapun mengenai ikan tersebut sudah tidak segar lagi dijelaskan kepada pembeli dan pembeli memaklumi hal tersebut dikarenakan jenis ikan laut akan sangat susah mencari yang segar. Adapun pedagang jenis dagangan daging telah menjual sesuai dengan etika bisnis Islam. Pedagang tidak menyembunyikan kecacatan daging, dan menjual daging berdasarkan pesanan pembeli, yakni apabila pembeli ingin diperbanyak lemak agar murah maka penjual mengikuti kehendak pembeli tersebut. Islam sangat mengutamakan bersikap jujur dalam berbisnis dan mengharamkan tindakan curang dalam berbisnis, salah satu kecurangan tersebut yakni menyembunyikan kecacatan barang. Dalam surah Al-baqarah ayat 284 telah menjelaskan tentang menyembunyikan kecacatan barang, yang artinya: "Kepunyaan Allah-lah segala apa yang ada di langit dan apa yang ada di bumi. Dan jika kamu melahirkan apa yang ada di dalam hatimu atau kamu menyembunyikan, niscaya Allah akan membuat perhitungan dengan kamu tentang perbuatanmu itu. Maka Allah mengampuni siapa yang dikehendakiNya dan menyiksa siapa yang dikehendaki-Nya; dan Allah Maha Kuasa atas segala sesuatu". (Depag, 2015: 49). Ayat diatas memberikan peringatan bahwa Allah akan membuat perhitungan bagi orang-orang yang menyembunyikan sesuatu. Dari uraian diatas dapat disimpulkan bahwa etika bisnis dalam transaksi jual beli di pasar tradisional 
Selasa Panam Kecamatan Tampan Kota Pekanbaru mengenai kejujuran dalam Kecacatan barang belum sesuai dengan ekonomi syariah.

b) Gharar. Gharar dalam jual beli ialah menjual sesuatu yang tidak jelas, belum tampak nyata baiknya. Seperti menjual buah yang belum matang, menjual barang yang belum jelas kondisinya dan menjual sesuatu yang belum tampak wujudnya. Setelah observasi yang penulis lakukan di pasar tradisional Selasa Panam Kecamatan Tampan Kota Pekanbaru. Pedagang pasar tradisional Selasa panam Kecamatan Tampan Kota Pekanbaru mengenai kelayakan barang dagangan, seperti pedagang makanan, sayuran, buah-buahan, daging, ikan, pakaian, tahu, dan tempe, barang harian, dan kosmetik sudah sesuai dengan ekonomi syariah. Hal ini terbukti karena pedagang menjual barang yang baik dan dalam keadaan baik, pedagang tidak pernah menjual barang yang basi atau tidak layak. Dalam hal ketidak jelasan barang dari segi kondisi barang dagangan yang terjadi di pasar tradisional Selasa Panam kecamatan Tampan Kota Pekanbaru dari pengamatan penulis bahwasanya telah sesuai dengan ekonomi syariah. Pedagang tidak menjual barang yang tidak jelas wujudnya, seperti menjual ikan yang belum berada ditangan, menjual barang harian yang masih berada diperjalanan, dan menjual buah yang masih berada di pohon dalam kondisi yang belum matang. Tindakan diatas tidak penulis jumpai di pasar Tradisional Selasa Panam Kecamatan Tampan Kota Pekanbaru, hal ini dikarenakan pedagang menyadari menjual sesuatu yang belum jelas sangat merugikan pedagang, dimana pada saat pedagang menjanjikan sesuatu yang belum ada akan menbuat orang yang dijanjikan berharap. Namun pada saat kondisi barang tidak bagus pembeli tidak ingin menerimanya karena tidak sesuai dengan yang dijanjikan.Inilah yang membuat pedagang tidak bisa melakukan transaksi jual beli pada saat barang belum jelas. (Kadir Rinto, 2018). Uraian diatas diperkuat dengan firman Allah dalam Al-Qur'an surah AlBaqarah ayat 276 mengenai gharar yang artinya: "Allah memusnahkan riba dan menyuburkan sedekah. Dan Allah tidak menyukai setiap orang yang tetap dalam kekafiran, dan selalu berbuat dosa". (Depag, 2015: 47).

c) Manipulasi barang. Manipulasi barang adalah perbuatan tercela yang harus dihilangkan, ini hanya terjadi bagi pedagang yang menjual demi meraih keuntungan sebesar-besarnya dengan menghalalkan segala cara. Praktek yang terjadi di pasar tradisional Selasa Panam Kecamatan Tampan Kota Pekanbaru mengenai manipulasi barang adalah sebagai berikut. Pedagang buah masih melakukan tindakan kecurangan yakni manipulasi dagangannya dengan menyuguhkan buah yang masih segar, pada posisi di atas yang mudah dilihat konsumen dan mencampur jenis buah yang berkualitas dengan yang kurang berkualitas. Disamping itu, cara lain dengan mengemas buah kedalam sebuah tempat dengan kualitas campuran. Pedagang juga meyakinkan calon pembeli bahwa buah dagangannya itu manis, segar, tahan lama, buah lokal, bahkan kadang-kadang disertai dengan sumpah. Kadangkala penjual buah durian mencampurkan antara durian yang berasal dari Sumatera Barat dengan durian yang berasal dari daerah Kampar. Karena ketidaktahuannya, sekalipun diberi kebebasan memilih sendiri pembeli masih terjebak oleh praktek yang kurang etis itu. Hal ini dilakukan pedagang untuk meminimalkan kerugian diakibatkan penyusutan yang terjadi pada dagangannya dengan 
melakukan trik-trik untuk menarik konsumen sekalipun cara itu kadangkala tidak benar. ada kasus pedagang jenis barang dagangan harian, bahwasanya pak Anto selaku pembeli dipasar tradisional Selasa Panam Kecamatan Tampan Kota Pekanbaru mengatakan pernah tertipu dalam membeli beras. Beliau membeli beras di pasar Tradisional Selasa Panam Kecamatan Tampan Kota Pekanbaru tepatnya disebuah gerai mobil yang mengadakan diskon besar, karena ada diskon pak Anto tertarik untuk membelinya karena akan mengirit biaya bulanan. Merek Anak Daro, harganya 120.000, namun sesampainya dirumah dan dimasak ternyata beras tersebut bukanlah beras Anak Daro, seperti besar bulok, berpasir, dan lengket tidak bertabur, niat saya ingin hemat malah jadi rugi ujar pak anto dalam sebuah wawancara singkat. (Sugianto, 2018). Dan dari pengalaman pribadi penulis, penulis pernah mengalami kejadian seperti ini dimana membeli beras disalah satu stand atau lapak di pasar Tradisional Selasa Panam Kecamatan Tampan Kota Pekanbaru, namun setiba dirumah dan melihat kondisi beras tersebut, ternyata beras tersebut bercampur dengan pasir dan pasir tersebut lumayan banyak dan membuat tidak nyaman saat memakannya. Pada pedagang jenis dagangan konveksi, obat-obatan, alat bangunan dan aksesoris melalui pengamatan penulis tidak terdapat tindakan yang menyalahi etika bisnis terkait manipulasi barang. Pedagang jenis barang dagangan diatas telah menjual barang dagangannya dengan jujur tanpa menyembunyikan sesuatu. Segala bentuk penipuan, baik dalam masalah jual-beli, maupun dalam seluruh mu'amalah diharamkan dalam Islam. Seorang muslim dituntut untuk berlaku jujur dalam segala urusannya, sebab keikhlasan dalam beragama nilainya lebih tinggi dari pada seluruh usaha duniawi. (Ahmad Mujahidin, 2015: 108). Jika pedagang menyembunyikan kualitas barang dan bermain curang dalam timbangan maka dapat dikategorikan sebagai penipu, sedangkan penipuan itu diharamkan. Hal ini dijelaskan dalam QS. An-Nisa ayat 29, yang artinya: "Hai orangorang yang beriman, janganlah kamu saling memakan harta sesamamu dengan jalan yang batil, kecuali dengan jalan perniagaan yang berlaku dengan suka sama-suka di antara kamu. Dan janganlah kamu membunuh dirimu; sesungguhnya Allah adalah Maha Penyayang kepadamu". (Depag, 2015: 83). Dari uraian diatas, dapat diketahui bahwa masih adanya kecurangan yang terjadi di pasar Tradisional Selasa Panam Kecamatan Tampan Kota Pekanbaru. Dan hal ini belum sesuai dengan ekonomi syariah.

d) Mengurangi timbangan. Mengurangi takaran dari suatu barang dan menipu pembeli adalah suatu perbuatan tercela dan menyalahi etika bisnis berdagang. Sebagai salah satu sumber konflik dan penipuan, ketetapan timbangan merupakan cermin kualitas moral seorang pelaku bisnis. Karena terlalu berorientasi pada profit, seorang pedagang berani meninggalkan nilai-nilai kemanusiaan sehingga disadari atau tidak ia memanipulasi hak orang lain, pada hal kita harus berbuat ihsan pada sesama. Dalam prakteknya yang terjadi di pasar tradisional Selasa Panam Kecamatan Tampan Kota Pekanbaru mengenai pengurangan takaran timbangan masih ada sebahagian pedagang yang mempraktekkannya.Sebagian pedagang menipu pembeli dengan mengurangi takarannya. Ini dilakukan dengan cara mengakali timbangan dan mengaturnya agar pembeli tidak menyadari. Pengurangan timbangan 
oleh pedagang dimotivasi adanya penutupan kerugian, biasanya para pedagang mengurangi kerugian akibat harga yang diberikan sangat murah dan tidak menutupi modal pedagang. Dalam kasus mengurangi timbangan ini hanya terjadi pada jenis dagangan lauk pauk, buah-buahan, dan barang harian yang ditimbang. Di pasar Tradisional Selasa Panam Kecamatan Tampan Kota Pekanbaru, masih ada yang berlaku curang dengan bermain pada timbangan. Ini terbukti dengan sebuah wawancara oleh ibu Fatimah mengatakan, beliau membeli buah di pasar Selasa, karena kebutuhan dan tuntutan kesehatan, ibu Fatimah membeli beberapa jenis buah di tempat yang berbeda. Namun, pada saat tiba dirumah, ia merasa curiga dengan berat buah tersebut sehingga menimbang buah tersebut karena mengalami sedikit keganjalan. Saat di timbang, buah anggur yang seharusnya $1 \mathrm{~kg}$ hanya 900 gr dan tidak sampai satu kilo. Saya kaget, namun karena sudah sampai rumah tidak mungkin mengembalikan buah tersebut ujar ibu Fatimah. (Hamdan Fatimah, 2018). Pedagang beralasan bahwa strategi untuk menarik pelanggan dengan cara bermain curang pada timbangan dan menurunkan harga dibawah rata-rata. Inilah yang sebagian pedagang terapkan dalam menarik pedagang. Karena sebagian pembeli tidak mengetahuinya dan ada yang mengetahuinya namun mereka tetap membeli barang tersebut karena tergiur harga yang murah, inilah yang membuat pedagang terus melakukan tindakan-tindakan yang menyalahi etika bisnis dalam transaksi jual beli. Islam sangat mengutamakan kebaikan dalam berbisnis dan mengharamkan tindakan curang dalam bisnis, salah satu kecurangan tersebut yakni mengurangi timbangan. Mengurangi timbangan apapun tujuan atau bdrapapun jumlahnya sangat dilarang dalam Islam. Hal ini dijelaskan dalam QS.alMutaffifin (83) ayat 1-6, yang artinya: "Kecelakaan besarlah bagi orang-orang yang curang, (yaitu) orang-orang yang apabila menerima takaran dari orang lain mereka minta dipenuhi, dan apabila mereka menakar atau menimbang untuk orang lain, mereka mengurangi. Tidaklah orang-orang itu menyangka, bahwa sesungguhnya mereka akan dibangkitkan, pada suatu hari yang besar, (yaitu) hari (ketika) manusia berdiri menghadap Tuhan semesta alam". (Depag, 2015: 587 588). Ayat ini memberikan peringatan keras pada para pedagang yang curang. Mereka dinamakan mutaffifin. Dalam bahasa Arab mutaffifin berasal dari kata tatfif atau tafafah, yang berarti pinggir atau bibir sesuatu. Pedagang yang curang atau yang dinamai mutaffif, karena ia menimbang atau menakar sesuatu hanya sampai bibir timbangan, tidak sampai penuh hingga penuh ke permukaan. Dalam ayat diatas, perilaku curang dianggap sebagai pelanggaran moral yang sangat berat. Pelaku diancam hukuman berat, yaitu masuk neraka wail. (Ahmad Mujahidin, 2016: 161). Kata wail memiliki arti azab, kehancuran atau sebuah lembah dineraka Jahannam. Hal ini menujukkan bahwa pedagang (pebisnis) yang melakukan kecurangan dalam menakar dan menimbang akan mendapat azab sehingga ditempatkan di lembah neraka Jahanam. Oleh karena itu pedagang sebaiknya berhati-hati dalam melakukan penakaran dan penimbangan agar ia terhindar dari azab. (Ahmad Mujahidin, 2016: 160). Dari uraian diatas dapat diambil kesimpulan bahwa etika bisnis dalam transaksi jual beli di pasar tradisional Selasa Panam Kecamatan Tampan Kota Pekanbaru mengenai kejujuran dalam menakar timbangan belum sesuai dengan Ekonomi Syariah.

2) Halal. Al-qur'an dengan tegas telah meletak- 
kan konsep dasar halal dan haram yang berhubungan transaksi dalam perdagangan. Menurut Mustaq Ahmad sebagaimana di kutip oleh Muhammad Djakfar (2016: 98), semua hal yang berhubungan dengan harta benda hendaknya dilihat dan dihukumi dengan kedua kriteria halal dan haram ini. Orang-orang Mekah yang hidup di zaman Rasulullah SAW sama sekali tidak membedakan antara bisnis dan riba. Bagi mereka keduanya adalah sama. Akhirnya al-Qur'an membangun konsep halal dan haram dengan penegasan bahwasanya jual beli adalah dihalalkan, sedangkan riba diharamkan. Pengharaman riba apapun bentuk dan namanya karena merupakan kedzaliman terhadap orang lain sehingga menciderai rasa keadilan. Sebab semua bentuk transaksi yang dilakukan dengan praktik jahat dilarang oleh Islam. Semua larangan itu berdasarkan pada suatu prinsip "jangan ada ketidakadilan dan jangan ada penipuan dalam segala aktivitas jual beli yang dilakukan oleh siapapun, esensi dari bisnis yang tidak dihalalkan adalah suatu bisnis yang didalamnya mengandung cara konsumsi yang tidak halal, atau melanggar dan merampas hak dan kekayaan orang lain. (Ahmad, 2013: 125). Praktek yang terjadi di pasar Tradisional selasa Panam Kecamatan Tampan Kota Pekanbaru melalui hasil Observasi penulis mengenai kehalalan barang dagangan yakni tidak ditemukan pedagang yang menjual barang yang haram untuk diperjualbelikan. Dalam perdagangan barang walaupun sedikit haram atau subhat tidak apa-apa dijual yang penting menguntungkan dan dapat memenuhi kebutuhan keluarga, hal seperti ini tidak pernah dilakukan oleh pedagang seperti mencampurkan ayam yang mati sebelum dipotong (sembelih) dengan ayam yang sudah dipotong dalam penjualannya atau ikan yang dicampur dengan formalin (pengawet) agar awet dan tahan lama. Penulis tidak menemukan suatu hal yang haram untuk dijual, pedagang pasar tradisional Selasa Panam kecamatan Tampan Kota Pekanbaru seperti pedagang ayam tidak pernah menjual ayam yang sudah mati sebelum di sembelih kepada pembeli dikarenakan pedagang ayam akan menyembelih ayam tersebut ketika ada pembeli yang membeli, adapun ayam yang sudah disembelih terlebih dahulu adalah untuk pedagang yang membeli potongan ayam dalam jumlah kecil dan ayam tersebut di sembelih hari itu juga dan dalam jumlah yang kecil. Argumen ini di perkuat dengan pernyataan pembeli bu Dewi dan bu Fatiah selaku pembeli tetap pasar tradisional Selasa Panam Kecamatan Tampan Kota pekanbaru. Kedua ibu ini merasa nyaman dalam berbelanja dan tidak khawatir tentang kehalalan barang yang akan mereka beli dikarenakan mereka melihat secara langsung proses pemotongan ayam tersebut. Menurut pengakuan ibu Fatiah, "saya tidak akan khawatir jika berbelanja ayam di pasar Selasa ini karena saya yakin ayam yang saya beli halal, saya sudah sering berbelanja disini dan mengetahui proses pemotongannya". (Fatiah, 2018).

3) Amanah. Amanah dalam bahasa Indonesia adalah dapat dipercaya. Kepercayaan adalah aset yang sangat berharga didunia bisnis (Sunyoto, 2015: 45). Amanah memiliki makna tanggung jawab dalam melaksanakan setiap tugas dan kewajiban moral yang dibebankan kepada setiap orang, baik dalam melaksanakan tugas penghambaan kepada Tuhan maupun tugas kemanusiaan antara sesamanya. (M.Nur, 2010: 27). Dalam prinsip manajemen, amanah menjadi kata kunci yang sangat penting, sampai dimana sebuah proses usaha ditangani dengan jujur, transparan, dan akuntabel. (Djunaidi, dkk, 2013: 56). Berdasarkan hasil observasi yang penulis lakukan di pasar tradisional Selasa Panam Kecamatan Tampan Kota Pekanbaru mengenai amanah, masih terdapat pedagang yang tidak amanah kepada pembeli. Di mana pedagang menawarkan barang dagangannya dengan disertai sumpah.Namun disaat pembeli mengeluh, sebagian pedagang tidak menerima keluhan setelah barang 
dibeli. Pedagang mengelak untuk menukar barangnya dikarenakan akan mengalami kerugian jika pedagang menukar barang tersebut, karena barang yang ditukar tersebut tidak dapat dijual kembeli. Seperti dalam sebuah wawancara dengan pedagang pasar, bu Rida mengatakan hal ini memang sudah umum diketahui oleh masyarakat. Dimana pedagang sering berjanji akan mengganti apabila barangnya rusak, namun saat barangnya rusak pedagang berdalih barangnya sudah sampai rumah, sudah beberapa hari dan lain sebagainya. (Efrida, 2018).

4) Keadilan. Dalam kitab Ihya Ulumuddin Imam Al-Ghazali sebagaimana dikuti oleh Yusuf Bin Ismail An-Nabhani dalam bukunya "Awas di Pasar ada Setan", sesungguhnya Allah telah memerintahkan sikap adil dan ihsan. Karena sikap adil merupakan jalan keselamatan yang dalam perniagaan berfungsi sebagi modal. Sementara sikap toleransi merupakan jalan untuk mencapai kemenangan dan keuntungan. Tentu dibilang termasuk orangorang berakal siapa saja yang sudah merasa puas hanya dengan kembalinya modal dalam berbagai transaksi dunianya. Dan begitu pula dengan berbagai transaksi akhirat. (Yusuf, 2015: 47). Dari hasil observasi penulis, bahwasanya keadilan di pasar Selasa Panam Kecamatan Tampan Kota Pekanbaru sudah sesuai dengan Ekonomi Syariah. Pedagang di pasar Selasa panam tidak membeda-bedakan pembeli satu dengan yang lainnya. Pedagang tidak memilah milih pembeli dan melayani pembeli dengan sama rata. Adapun pada pedagang jenis dagangan konveksi, pedagang melakukan proses negosiasi mengenai harga barang. Hal ini yang membuat perbedaan dikarenakan negosiasi setiap orang berbedabeda. Jenis dagangan konveksi dalam hal menarik pembeli iyalah melakukan proses tawar menawar, sehingga hasil dari setiap pembeli bisa jadi berbeda. Namun hal ini bukanlah termasuk tidak adil, dikarenakan kebutuhan dan kualitas setiap orang berbeda sehingga hasil tawar menawarpun akan berbeda.
5) Tidak Memaksa. Banyak orang yang susah untuk berperilaku ramah antar sesama. Seringkali bermuka masam ketika bertemu dengan orang yang tidak disukainya atau memilih untuk berperilaku tidak ramah. Padahal, ramah merupakan sifat terpuji yang dianjurkan oleh agama Islam untuk siapa saja dan kepada siapa saja. Dengan ramah, maka banyak orang yang suka, dengan ramah banyak pula orang yang senang. Karena sifat ramah merupakan bentuk aplikasi dari kerendahan hati seseorang. Murah hati, tidak merasa sombong, mau menghormati dan menyayangi merupakan inti dari sifat ramah. Oleh karena itu, bersikap ramahlah dalam transaksi jual beli karena dapat membuat konsumen senang sehingga betah atau bahkan merasa tentram jika dalam bertransaksi. Hasilnya pedagang pasar tradisional selasa Panam Kecamatan Tampan Kota Pekanbaru tidak melakukakan pemaksaan kepada pembeli dan ini sudah sesuai dengan ekonomi Syariah.

6) Ikhtikar. Jangan menimbun barang dagangan pada saat masyarakat sedang membutuhkannya dengan tujuan memperoleh laba sebanyak-banyaknya. Penimbunan barang adalah halangan terbesar dalam pengaturan persaingan pasar Islam, hal tersebut dikarenakan pengaruhnya terhadap jumlah barang yang ditimbun, dimana pedagang memilih untuk menahan barang dagangannya dan tidak menjualnya karena menunggu naiknya harga. (Hakim, 2012: 168). Melalui hasil observasi yang penulis lakukan di pasar tradisional Selasa Panam Kecamatan Tampan Kota Pekanbaru mengenai praktek menimbun barang, bahwasanya pedagang pasar tradisional Selasa Panam tidak melakukan praktek ikhtikar. Menimbun disini yaitu sengaja menumpuk barang untuk mengambil keuntungan yang besar. Hasilnya bahwa pedagang pasar tradisional Selasa Panam Kecamatan Tampan Kota Pekanbaru tidak melakukakan penimbunan barang, ini sudah sesuai dengan ekonomi Syariah. 
7) Riba. Rasulullah mengajarkan agar para pedagang senantiasa bersikap adil, baik, kerja sama, amanah, tawakal, qana'ah, sabar, dan tabah. Sebaliknya beliau juga menasehati agar pedagang meninggalkan sifat kotor perdagangan yang hanya memberikan keuntungan sesaat, tetapi merugikan diri sendiri duniawi dan ukhrawi. Akibatnya kredibilitas hilang, pelanggan lari, dan kesempetan berikutnya sempit. (Mujahidin: 169). Hasilnya bahwa praktek riba masih dan terjadi di Pasar Selasa Panam, dimana memberikan pinjaman kepada pedagang yang sedang membutuhkannya dengan memberikan keringanan dalam membayarnya yakni dengan mencicilnya, kemudian mengambil keuntungan yang banyak dari harta pokok yang di pinjam tersebut dengan alasan berbagai macam.

\section{SIMPULAN}

\section{Kesimpulan}

Berdasarkan hasil penelitian dan pembahasan yang telah dilakukan dapat ditarik beberapa kesimpulan dari penelitian etika bisnis dalam transaksi jual beli di Pasar Tradisional Selasa Panam Kecamatan Tampan Kota Pekanbaru ditinjau Menurut Ekonomi Syariah sebagai berikut:

1. Bahwasanya pada Poin Halal, Amanah, Keadilan, Tidak Memaksa dan Ikhtikar telah sesuai dengan Etika Bisnis dalam transaksi Jual Beli menurut Ekonomi Syariah. Namun pada poin Jujur dan Riba masih terdapat tindakan kecurangan yang tidak sesuai dengan Etika Bisns dalam Transaksi Jual Beli menurut Ekonomi Syariah.

2. Berdasarkan hasil observasi yang diperoleh dari para pedagang di pasar tradisional Selasa Panam Kecamatan Tampan Kota Pekanbaru yang ditinjau menurut Ekonomi Syariah secara umum belum diterapkan dengan baik oleh para pedagang. Hal ini dapat terlihat pada hasil observasi dan didukung oleh wawancara yang penulis lakukan, yakni para pedagang masih belum menerapkan sikap jujur dalam berjual beli, pedagang masih tidak menjelaskan keadaan barang (kecacatan barang), dan para pedagang masih bermain curang dalam takaran, yakni mengakali takaran timbangan demi meraih untung yang lebih besar. Memaksa pembeli untuk membeli dan masih melakukan praktik riba. Dalam pandangan Islam aspek Kecurangan di atas tidak sesuai dengan ekonomi Syariah.

\section{DAFTAR PUSTAKA}

Abdullah, Ma’ruf, 2011, "Wirausaha Berbasis Syariah”, Banjarmasin: Antasari Pers.

Agama, Departemen RI, 2015, "Al-Qur'an dan Terjemahannya", Bandung: Syaamil Cipta Midya.

Ali, Kamal, 2017, "Berbisnis dengan Cara Rasul", Bandung: Jember.

Alma, Buchori dan Donni Juni Priansa, 2014, "Manajemen Bisnis Syaria", Bandung: Alfabeta.

Alma, Buchori, 2014, "Dasar-Dasar Etika Bisnis Islami”, Bandung: CV. Alfabeta.

Alma, Bukhori, 2013, "Manajemen Bisnis Syariah", Bandung: Alfabeta

An-Nawawi, Imam, 2013, "Syarah Syahih Muslim", Jakarta: Darus Sunnah Press.

Anoraga, Pandji, 2011, "Pengantar Bisnis", Jakarta:PT Rineka Cipta.

At-Tarmizi, 1426 H, "Sunan At-Tarmizi", Juz 3, Nomor hadis 1209, CD Roo, Maktabah Kutub Al-Mutun, Silsilah Al-'Ilm An-Nafi', Seri 4,Al-Ishdar Al-Awwal.

Aziz, Abdul, 2013, “Etika Bisnis Perspektif Islam Implementasi Etika Islami Untuk Dunia Usaha", Bandung: Alfabeta

Azwar, Adiwarman, Karim, 2018, "Sejarah Pemikiran Ekonomi Islam” Jakarta: Raja Grafindo Persada.

Badroen, Faisal, 2016, "Etika Bisnis dalam Islam", Jakarta: Kencana.

Basri, Helmi, 2010, "Fiqih Ibadah", Pekanbaru: Suska Press.

Binbaz, 2018, http://www.binbaz.org.sal mat/19167. Diakses pada tanggal 17 April 2018, 10.00 WIB. 
Burhan, M. Bungin, 2015, "Metodologi Penelitian Kuantitatif", Jakarta: PT. Kencana Prenada Media Group.

Burhanuddin, 2015, "Etika Individu Pola Dasar Filsafat Moral”, Jakarta: PT. Rineka Cipta.

Damsar, 2012, "Sosiologi Ekonomi", Jakarta: PT. Raja Grafindo Persada.

Efrida, (Pedagang), 2018, "Wawancara Pasar selasa Panam", (5 Januari)

Fatiah, (Pembeli), 2018, "Wawancara, Pasar Selasa Panam”, (17 Januari)

Fatimah, Hamdan, (Pembeli), 2017, "Wawancara, Pasar Selasa Panam”, (Panam, 12 Desember)

Google, 2018, https://www.google.com/amp/s/ niaas8.wordpress.com/pengertian-pasartradisional-dan-modern/amp/. Diakses pada tanggal 1 januari 2018, 19.00 WIB.

Hakim, Lukman, 2012, "Prinsip-Prinsip Ekonomi Islam”, Surakarta: Erlangga.

Harahap, Sofyan S, 2011, "Etika Bisnis dalam Perspektif Ekonomi Islam", Jakarta: Salemba Empat.

Hartono, 2014, "Statistik Untuk Penelitian", Yokyakarta: Pustaka Pelajar.

Hasan, Ali, 2012, "Manajemen Bisnis Syariah Kaya Dunia Terhormat di Akhirat", Yogyakarta: Pustaka Pelajar.

Surat Melita,2016, http://suratmelita. blogspot.co.id/2016/09/makalahp asartradisionaldanpasarmodernpendidikan-ips-sosialekonomidownloadelitasuratmipengertian-manfaat-sebabakibat-indonesia-keuangan.html? $m=1$. Diakses pada tanggal 1 januari 201819.20 WIB.

Jakfar, 2013, "Studi Kelayakan Bisnis", Jakarta: PT. Kencana Prenada Media Group.

Jusmaliani, 2012, "Bisnis Berbasis Syariah", Jakarta: Bumi Aksara.

Kadir, 2010, "Hukum Bisnis Syariah dalam alQur'an”, Jakarta: Amzah.

Kasmir, dan Jakfar, 2010, "Study Kelayakan Bisnis", Jakarta: Kencana.

Majah, Ibnu, 1426 H, "Sunan Ibnu Majah, Juz 2, Nomor hadis 2139, CD Room", Maktabah Kutub Al-Mutun, Silsilah Al-'Ilm An-Nafi', Seri 4,Al-Ishdar Al-Awwal.
Malik, Imam, bin Annas, 2016, "Al-Muaththa" Imam Malik", Penerjemah Muhammad Iqbal Qadir, Jakarta: Pustaka Azzam.

Mardani, 2013, "Hukum Ekonomi Syariah", Jakarta: PT Fajar.

Mhd. Nuruddin, Ali, 2016, "Zakat sebaggai Instrumen dalam Kebijakan Fiskal”, Jakarta: PT Raja Grafindo Persada.

Miftahul, H. Huda, 2017, "Aspek Ekonomi dalam Syariat Islam", Mataram Konsultasi dan Bantuan Hukum.

Muhammad, Syekh, Yusuf Qardhawi, 2017, "Halal dan Haram dalam Islam", Surabaya: PT Bina Ilmu.

Mujahidin, Akhmad, 2014, "Ekonomi Islam (Sejarah, Konsep, Instrumen, Negara, dan Pasar)", Jakarta: PT raja Grafindo Persada.

Mursida, Umi, 2012, "Penerapan Etika Bisnis Islam dalam Transaksi Jual Beli Di Pasar Tradisional (Studi kasus pasar Betung Kecamatan Sekincau Kabupaten Lampung Barat)", Jurnal Ekonomi Syariah.

Natadipurba, Chandra, 2016, "Ekonomi Islam 101”, Bandung: PT Mobidelta Indonesia.

Nejatullah, Muhammad, Siddiqi, 2013, "Kegiatan Ekonomi dalam Islam, diterjemahkan oleh Anas Sidik", Jakarta: Bumi Aksara

Observasi, 2017, "Pasar Selasa Panam", (12 desember)

Putra, Doni, (Juru Tagih), 2017, "Wawancara, Pasar Selasa Panam", (19 Desember)

Putri, Yuliza, 2017, (Pedagang Pasar), "Wawancara, Pasar Selasa Panam", (Panam, 12 Desember)

Qardhawi, Yusuf, 2011, "Norma dan Etika Ekonomi Islam", diterjemahkan oleh Zainal Dahlia Husin, Jakarta: Gema Insani Pers.

Rahman, Abdul, Ghazaly, dkk, 2010, "Fiqih Muamalah", Jakarta: Kencana.

Rahman, Afzahul, 2011, "Doktrin Ekonomi Islam", Yogyakarta: Dana Bakti Wakaf.

Riva'I, Veithzal, 2012, "Islamic Marketing (Membangun dan Mengembangkan Bisnis dengan Praktik Marketing Rasulullah)', Jakarta: PT. Gramedia Persada Utama.

Rumaysho, 2018, "Penipuan dan pengelabuan dalam jual beli', https://rumaysho.com/7154- 
penipuan-dan-pengelabuan-dalam-jual-beli. html. Diakses pada tanggal 17 April 2018, 10.00 WIB.

Sahrani, Sohari dan Ru'fah Abdullah, 2011, "Fiqih Muamalah untuk Mahasiswa UIN/IAIN/ STAIN/PTAIS dan Umum", Bogor, Ghalia Indonesia.

Soehartono, Irwan, 2013, "Metode Penelitian Sosial", Bandung: PT. Remaja Rosdakarya

Sugiono, 2013, "Metode Penelitian Kuantitatif, Kualitatif dan Kombinasi", Bandung: Alfabeta.

Suhendi, Hendri, 2015, "Fiqih Muamalah (Membahas Ekonomi Islam, Kedudukan Harta, Hak Milik, Jual Beli, Bunga Bank dan Riba, Musyarakah, Ijarah, Etika Bisnis dll)", Jakarta: PT Raja Grafindo Persada.

Suwiknyo, Dwi, 2010, "Kompilasi Tafsir Ayat-Ayat Ekonomi Islam", Yogyakarta: Pustaka Pelajar.

Syafei, Rachmat, 2010, "Fiqih Muamalah", Bandung: Pustaka Setia.

Syaf'i, Imam, Abu Abdullah Muhammad bin Idris, 2016, "Ringkasan Kitab al-Ulum", diterjemahkan oleh Amiruddin, Jakarta: Pustaka Azzam.

Syafii, H.A. Jafri, 2015, "Fiqih Muamalah", Pekanbaru: Suska Pres.

Tanjung, Hendri \& Abrista Devi, 2013, "Metodologi Penelitian Ekonomi Islam”, Jakarta: Gramata Publishing.

Tantri, Francis, 2005, "Pengantar Bisnis", Jakarta: Rajagrafindo

Tantri, Francis, 2014, “Pengantar Bisnis”, Jakarta: PT Raja Grafindo Persada.

Umar, Husein, 2015, "Metode Penelitian Untuk Skripsi dan Tesis Bisnis", Jakarta: Raja Grafindo Persada.

Wardi, Ahmad, Muslich, 2010, "Fiqih Muamalat", Jakarta: Amzah

Wati, Soleh, 2018, "Etika Bisnis dalam Transaksi Jual Beli di Pasar Tradisional Selasa Panam Kkecamatan Tampan Kota Pekanbaru Ditinjau Menurut Ekonomi Syariah", Jurusan Ekonomi Syariah Fakultas Syariah dan Hukum Universitas Islam Negeri Sultan Syarif Kasim Riau, 1439 H.

Yunia, Ika, Fauzia, 2013, "Etika Bisnis dalam
Islam", Jakarta: Kencana.

Yusuf, Bin Ismail An-Nabhani, 2015, "Awas di pasar ada Setan", terjMuhammad AlMighwar, Jakarta: GriyaIlmu.

Zaitun, 2016, "Hukum Islam Juornal For Islamic Law", Fakultas Syariah dan Ilmu Hukum. 